\title{
The Responsibility of Private Pawnshops in Facilitating Ecologically-Friendly Marine Economies
}

\author{
Siti Malikhatun Badriyah", Siti Mahmudah, Amiek Soemarmi, R. Suharto, Marjo, \\ Muhammad Haidar Fakhri Allam, Adina Larasati
}

Department of Law, Faculty of Law, Universitas Diponegoro, Semarang, Indonesia

Received October 6, 2021; Revised November 6, 2021; Accepted December 10, 2021

\section{Cite This Paper in the following Citation Styles}

(a): [1] Siti Malikhatun Badriyah, Siti Mahmudah, Amiek Soemarmi, R. Suharto, Marjo, Muhammad Haidar Fakhri Allam, Adina Larasati, "The Responsibility of Private Pawnshops in Facilitating Ecologically-Friendly Marine Economies," Environment and Ecology Research, Vol. 9, No. 6, pp. 362 - 369, 2021. DOI: 10.13189/eer.2021.090604.

(b): Siti Malikhatun Badriyah, Siti Mahmudah, Amiek Soemarmi, R. Suharto, Marjo, Muhammad Haidar Fakhri Allam, Adina Larasati (2021). The Responsibility of Private Pawnshops in Facilitating Ecologically-Friendly Marine Economies. Environment and Ecology Research, 9(6), 362 - 369. DOI: 10.13189/eer.2021.090604.

Copyright $\mathrm{O} 2021$ by authors, all rights reserved. Authors agree that this article remains permanently open access under the terms of the Creative Commons Attribution License 4.0 International License

\begin{abstract}
As the largest maritime country in the world, Indonesia has extremely large and diverse natural resources, both in the form of renewable and non-renewable natural resources. The natural wealth must be managed optimally to improve the welfare and prosperity of the Indonesian people. In the operation of marine economy, financial services also have a huge effect on the development of marine industry as a whole. This paper aims to analyze the supporting activities of auxiliary operations of financial services, especially pawnshops, in supporting the development of the ecologically friendly marine economies, particularly for vulnerable small fishermen. The research method used is empirical juridical by conducting library research related to legal principles, legal rules and legal norms related to private pawning. In addition, field research was also conducted to obtain primary data related to the existence of private pawnshops in the development of the fishing industry and its environmentally friendly approaches. The results of the study show that pawning has actually great potential for industrial development, including the fishing industry; but even though there are arrangements to facilitate the supervision of private pawning businesses, in practice there are still not many private pawns registered. Although not many have been registered, from time to time it shows progress. The existence of private pawnshops in Indonesia in the direct development of the fishing industry is still not widely used.
\end{abstract}

Keywords Ecologically-Friendly Approach, Marine
Economies, Financial Services, Private Pawn, Fishery Industry

\section{Introduction}

Indonesia is the largest archipelagic country in the world with approximately 17,504 islands in Indonesia, and 16,671 islands have been standardized and registered with the United Nations (UN). The area of Indonesian waters is 6.4 million $\mathrm{km}^{2}$ which consists of 0.29 million $\mathrm{km}^{2}$ of territorial sea, 3.11 million $\mathrm{km}^{2}$ of inland waters and archipelagic waters, and 3.00 million $\mathrm{km}^{2}$ of the Indonesian Exclusive Economic Zone (EEZ). In addition, Indonesia has an additional water zone area of 0.27 million $\mathrm{km}^{2}$, the continental shelf area of 2.8 million $\mathrm{km}^{2}$, and a coastline length of $108,000 \mathrm{~km}$ [1]. As the largest maritime country in the world, Indonesia has very large and diverse natural resources, both in the form of renewable natural resources (fisheries, coral reefs, seagrass beds, mangrove forests, seaweed, and biotechnology products), non-renewable natural resources (oil and gas), natural gas, tin, iron ore, bauxite, and other minerals), marine energy (such as tides, waves, wind, OTEC (Ocean Thermal Energy Conversion), as well as marine and small island environmental services for marine tourism, sea transportation, and sources of biodiversity and germplasm). The natural wealth is one of the basic 
capitals that must be managed optimally to improve the welfare and prosperity of the Indonesian people. Fish resources in Indonesia's seas cover 37\% of the world's fish species, of which several species have high economic value, such as tuna, shrimp, lobster, reef fish, various types of ornamental fish, shellfish, and seaweed. The sustainable potential of Indonesia's marine fish resources is estimated at 12.54 million tons per year spread over the territorial waters of Indonesia and the waters of the Indonesian Exclusive Economic Zone (ZEEI) [2].

As one of the 10 largest fish-producing countries in the world, Indonesia has large marine resources, including marine biodiversity and non-biological diversity $[3,4]$. This is very potential in the development of the fishing industry. The development of these businesses requires large capital, so the need for financing is also very large. As one of the materials guarantees to guarantee creditors' receivables, pawns have great potential for industrial development. In this regard, business actors in starting a business or developing their business always need financing. This financing can come from self-financing and financing from other parties, both from banks and non-bank institutions [5]. In various activities, especially business activities, there is always an agreement as a legal basis for the parties in the activity [6].

Nonetheless, there are still many illegal private pawn practices in people's lives, and there are still many deviations from the principles of pawning and the principle of guarantees in general. The problem in this research is the existence of private pawnshops in the development of the fishing industry. This study attempts to originally investigate the role of pawnshop financial services in increasing the capability of the environmentally friendly fishing industry sector, considering Indonesia's ecological wealth that needs to be maintained for the prosperity of the people as well as sustainable environmental preservation.

\section{Literature Review}

The need for existence of private pawns in the development of the fishery industry started from the marine resource potential of the fishing industry in Indonesia which is ecologically diverse and rich, resulting in great potential for financing development to meet industrial needs. However, in case of financial service of pawnshops, the implementation there are still not many private pawns registered and not evenly distributed in various regions. Therefore, it is still not widely used in the development of the fishing industry, let alone in supporting the environmentally friendly business. This is because the existence of legal private pawnshops in the community is not widely known and the people in general still use government pawnshops, or even many still borrow through illegal private pawns.
As a country that has very wide waters and marine resources, Indonesia has a huge potential for developing the fishing industry [7]. As the largest maritime country in the world, Indonesia has very large and diverse natural resources, both in the form of renewable natural resources (fisheries, coral reefs, seagrass beds, mangrove forests, seaweed, and biotechnology products), non-renewable natural resources (oil and gas), natural gas, tin, iron ore, bauxite, and other minerals), marine energy (such as tides, waves, wind, OTEC (Ocean Thermal Energy Conversion), as well as marine and small island environmental services for marine tourism, sea transportation, and sources of biodiversity and germplasm). The natural wealth is one of the basic capitals that must be managed optimally to improve the welfare and prosperity of the Indonesian people. Fish resources in Indonesia's seas cover 37\% of the world's fish species, of which several species have high economic value, such as tuna, shrimp, lobster, reef fish, various types of ornamental fish, shellfish, and seaweed. The sustainable potential of Indonesia's marine fish resources is estimated at 12.54 million tons per year spread over the territorial waters of Indonesia and the waters of the Indonesian Exclusive Economic Zone (ZEEI) [2].

However, the current practices are not considered sustainable and many marine ecosystems are ecologically endangered, as there are no regulations to directly link between financial services and fishery sector [8-10]. In this context, the huge potential for developing the fishing industry also has the potential to increase the existence of private pawnshops. On the other hand, the lack of private pawnshop companies in various regions can be an opportunity for the development of pawnshops to help finance the development of the fishing industry. At present, private pawning is regulated in the Financial Services Authority Regulation Number 31 /POJK.05/2016 concerning Pawning Business. Since the issuance of OJK regulations, the existence of private pawning has become a legal business. The OJK regulation is intended to facilitate supervision of private pawning, so as to provide legal protection for the parties. The issuance of the Financial Services Authority Regulation has influenced the regulation of collateral law, especially the Pawning system as one of the guarantees for material goods in Indonesia [11]. So far, positive law that regulates pawning as collateral with movable objects is regulated in Articles 1150-1160 of the Civil Code. Article 1150 of Civil Code states that a pawn is a right obtained by a debtor on a movable property, which is handed over to him by a debtor or by another person on his behalf, and which gives the debtor the power to take payment of the goods first over the debtors other; with the exception of the costs of auctioning the goods and the costs that have been incurred to save them after the goods have been pawned, which costs shall take precedence. The emergence of the policy on pawnshops which provides regulation and supervision 
of private pawnshops is expected to strengthen the existence and provide legality and supervision of private pawnshops in the financing business for both consumptive and productive needs. With the policy, it is hoped that it can provide balanced legal protection for both parties, because it will be easier to supervise.

\section{Methods}

This study aims to investigate the role of pawnshop financial services in increasing the financial capability of the environmentally friendly fishing industry sector. The development of the fisheries industry in Indonesia certainly involves many business actors in various fields, both capture fisheries and aquaculture. These business actors in developing their businesses often get capital from other parties, namely financial institutions. In this case, in general, creditors require special guarantees for the security of their receivables. One of the collaterals that is widely used is a private mortgage. Pawns are widely used in people's lives, among others, by business actors, especially micro, small and medium enterprises. However, the use of legal private pawns in the community is still not much compared to government pawns, including in the development of the fishing industry. Interactions between human societies and fish stocks have played an important part in the history [12].

The juridical basis for this study is by examining the pawning as stated in Article 1150-1160 of Civil Code. Pawn is one of the collateral-based financial service, giving rise to material rights. Therefore, the pledge creates a Preferred Right for the creditor holding the lien. Thus, the creditor holding the mortgage has the right to prioritize the settlement of his receivables than other creditors. Article 1133 of the Civil Code states that receivables that take precedence are receivables with privileges, liens and mortgages. Pawnshops are all businesses related to providing loans with collateral for movable goods, deposit services, appraisal services, and/or other services, including those held based on sharia principles (Article 1 point 1 policy for pawnshops). Pawnshops are private pawnshops and government pawnshops regulated and supervised by the Financial Services Authority (Article 1 point 2 on pawnshops). The object of the pledge is a movable object, whether bodily or immovable (receivable). Private pawnshop company is a legal entity that conducts pawn business (Article 1 point 3 of the pawn business regulation).

Furthermore, the approach method used in this study is an empirical juridical approach. In this case, a systematic, chronological description and analysis will be carried out, based on scientific principles regarding the existence of private pawnshops in Indonesia with existing legal theories and/or laws and regulations related to legal protection for parties in the implementation of private pawning in Indonesia. The research method used is empirical juridical by conducting library research related to legal principles, legal rules and legal norms relating to private pawning. In addition, field research was also conducted to obtain primary data related to the existence of private pawnshops in the development of the fishing industry and its environmentally friendly approaches.

\section{Results}

So far, only government pawnshops have the legality of pawnshops. This does not mean that there are no private pawnshops. In practice, there are many private pawnshops, but they are not legalized. As a result, there are many deviations from the principles of pawning and agreements in general, even online pawning. The increasing number of pawnshop business activities and the emergence of various irregularities have prompted the government to regulate this private pawnshop. This pawnshop business uses the principle of pawning as regulated in Article 1150 of the Civil Code. The legal relationship in pawning is basically an agreement. The parties in the Pawn are the Pawnshop Company as the Pawn Holder (guarantee) and the customer or by their proxies. Private Pawnshop Company is a legal entity that conducts Pawnshop Business (Article 1 Point 3 Financial Services Authority Regulation on Pawnshop Business).

The Financial Services Authority Regulation for Pawnshops stipulates that private business actors are required to obtain a permit. With this arrangement, the existence of private pawning becomes a legal business. Private pawnshop arrangements aim to increase financial inclusion for the lower middle class and micro, small and medium enterprises. In addition, for the implementation of a pawn business that provides easy access to loans, especially for the lower middle class and micro, small and medium enterprises, it is necessary to have a legal basis for the Financial Services Authority in supervising the pawnshop business in Indonesia, as well as a legal basis to supervise the pawnshop business to create a sound pawn business, to provide legal certainty for pawnshop business actors, and to protect consumers. The rapid development of business in Indonesia makes more and more business actors (including in the fishing industry) and consumers need funds to fulfill both consumptive and productive needs. These funds can come from internal sources or other parties. The existence of institutions that provide capital (loans) is very important for the community, especially small-scale business [13].

Pawn companies are one of the institutions that provide loans that offer easy access to loans so that they become an alternative solution to the community in the midst of the difficulty of obtaining loans from lending institutions such as banks. Pawnshops are a solution for people who need funds easily, quickly, and safely. People can get 
funds without having to sell their valuables. Pawnshops can serve funding needs ranging from tens of thousands to hundreds of millions of rupiah with guarantees for electronic goods, motor vehicles, gold, jewelry, and other types of goods that continue to grow. The development of private pawns registered and licensed by the Financial Services Authority can be seen in Table 1 .

Table 1 shows an increase in the number of companies and financing carried out by private pawn companies. According to Pratama [14], head of the Supervision Department of the Non-Bank Financial Industry (IKNB), this is supported by Badriyah et al. [3] showing that there were only 24 pawnshop companies out of a total of 585 . The increase in the number of pawn companies cannot be separated from the large potential of the pawn business in Indonesia. The characteristics of a fast, easy and simple business make pawn services become one of the main alternatives sought by people who need funds. In addition, the increase in private pawn companies during the Covid-19 pandemic was due to the need for pawn services as an alternative for the lower middle class, as well as micro, small and medium enterprises (MSMEs) to obtain loan funds. In addition, the risk of the pawn business is relatively well managed because the collateral goods are under the control of the pawnshop.

Private pawn companies that have permits are still very few compared to private pawnshops that are not registered. Private unregistered pawn companies are very difficult to control. OJK does not have the authority to supervise, so there are still private pawning practices that are not in accordance with the principles of pawnshops and deviate from the principles of guarantee law in general and contract law. The legal relationship between the parties in a pawn is basically an agreement, namely a pawn agreement. This pledge agreement is consensual, obligatory and in free form. The pawn agreement is an accessor agreement, meaning that the pawn agreement is a follow-up (additional) agreement to the main agreement. Thus, the presence or absence of a pawn depends on the presence or absence of the principal agreement.

Pawning occurs because of the transfer of power over the pawned goods to the creditor who holds the pledge. The surrender of the pledged object from the hand of the pawnbroker to the holder of the pawn is absolute for the occurrence of the pledge. Thus, there must be a real surrender, namely a direct hand-to-hand submission. If the submission is made in a constitutum possessorium, it does not result in a pledge. This is because there is a condition for inbezitstelling in pawning as stipulated in Article 1132 Paragraph (2) of the Civil Code which states that there is no lien if the pledged item is left in the hands of the debtor or pawnbroker or returns to the power of the debtor or pawnbroker at the will of the creditor pawnbroker.

The object that becomes the object of the pledge is a movable object, both tangible and intangible. The subject of the pawn is the pawnbroker and the holder of the pawn. The subject of the pawn agreement is the party giving the pledge and the holder of the pledge. The pawn holder in this case is a company in the form of a legal entity as stated in Article 1 Number 3 of POJK Number $31 /$ POJK.05/2016. The creditor holding the pledge has the right to take repayment of the pledged goods before other creditors. This is a consequence of the preference rights owned by the holders of material guarantees, including the Pledge Holders.

In the law of guarantees there are also legal principles of guarantees that can be implied in Articles 1131 and 1132 of the Civil Code. Article 1131 of the Civil Code states that all objects of a debtor, both movable and immovable, both existing and new in the future, become collateral for all personal engagements of the debtor. Article 1132 of the Criminal Code. The Civil Code states that the objects referred to in article 1131 serve as mutual guarantees for creditors and the proceeds from the sale of the goods are divided among creditors in a balanced manner according to the size of their respective receivables, unless there are valid reasons to prioritize one receivable over another. In civil law, it can be concluded that there is the principle of schuld and haftung, the principle of trust, the principle of morality, the principle of creditor parity, the principle of balance and the general principle, namely the existence of equal rights of creditors to the assets of their debtors. Thus, if there is no special guarantee, one of which is a pawn, the creditor is domiciled as a concurrent creditor. Therefore, the existence of a pawn to guarantee creditors' receivables is very necessary.

Table 1. The Development of Private Pawning in Indonesia

\begin{tabular}{|c|c|c|c|}
\hline Private Pawn & $\mathbf{2 0 1 9}$ & $\mathbf{2 0 2 0}$ & $\mathbf{2 0 2 1}$ \\
\hline \multirow{2}{*}{ Private Pawnshop } & 83 Licensed & 61 Licensed & 74 Licensed \\
& 18 Registered & 30 Registered & 915 billion IDR \\
\hline Asset & 423 billion IDR & 725 billion IDR & 520 billion IDR \\
\hline Loan Performance & 306 billion IDR & 420 billion IDR & \\
\hline
\end{tabular}




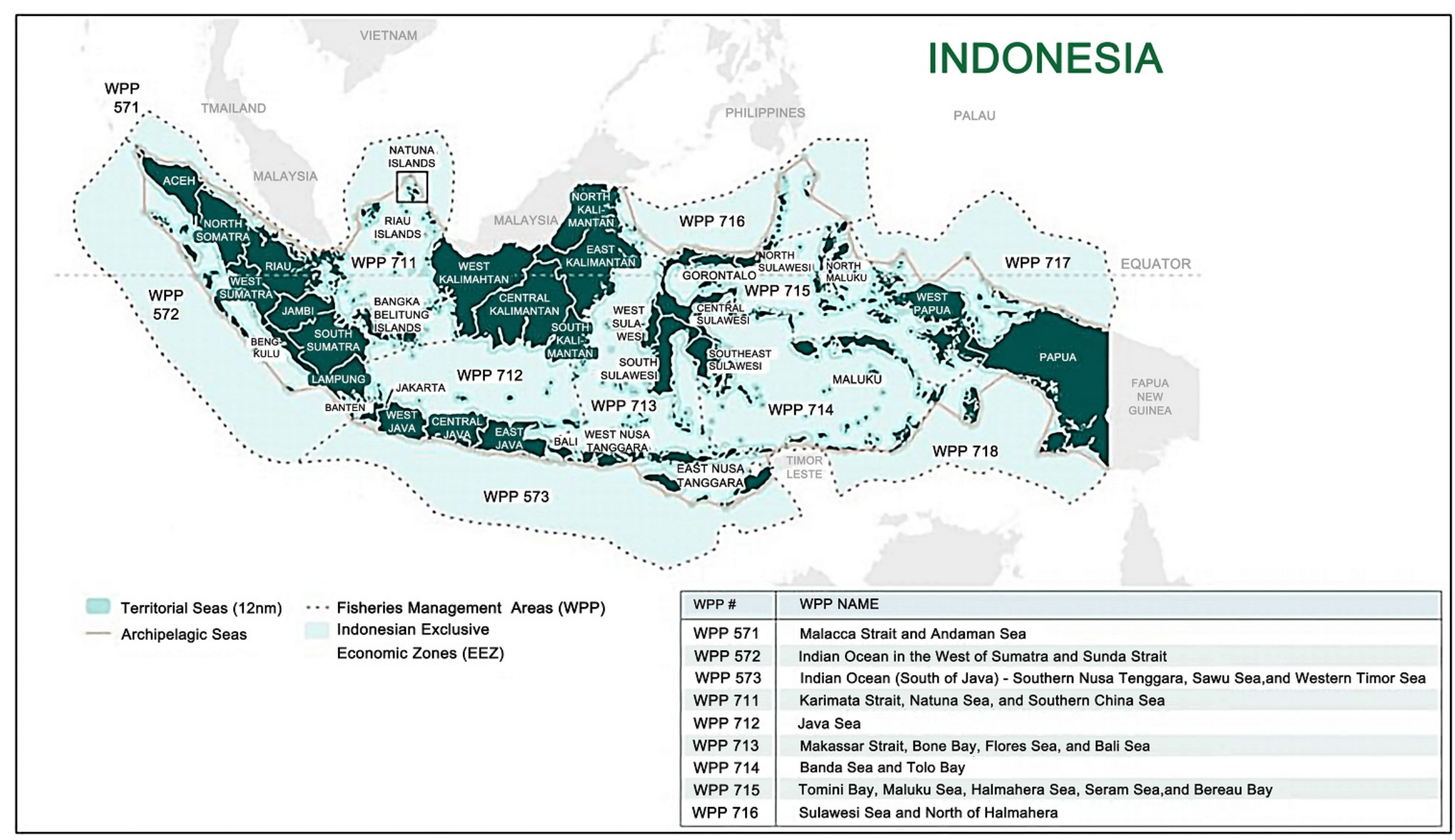

Source: [15]

Figure 1. Fisheries Management Area Division in Indonesia 
Taking into account the natural environment and the characteristics of fishery resources, in accordance with the Decree of the Minister of Marine Affairs and Fisheries No. $01 / \mathrm{Men} / 2009$, Indonesian waters are divided into 11 fisheries management areas (Figure 1) [15]. The results highlighted that for small-scale fishing, as they are facing difficulties in accessing formal financial services, the existence of pawns helps them so much to operate their activities [16]. Previous research examines the relationship between small-scale fishing with ecological sustainability in the context of marine resources [17-24]. Schuhbauer et al. [25] showed that financial assistance can help the capability of small-scale fishing which may result in sustainable fish stocks. In this context, Jacquet \& Pauly [26] argue that funding is a critical priority to create a sustainable small-scale fishing.

As one of the implementations of financial assistance to increase the financial capacity of the fishing industry in general, Indonesia has made it easier for this industry to access financial services, such as by using pawnshop to fishery industry. Pawns always develop from time to time, and high market demand makes this business have great interest in running a pawnshop business [27, 28]. In various countries in the world, including the Philippines, Malaysia, Russia, Romania and various other countries including Indonesia, pawns are no longer only used by the lower middle class, but have become a necessity for all levels of society, and it is also used in fishery industry to make it more environmentally friendly [6, 29-33].

In addition, the findings also encourage the involvement of the private sector and small and medium scale loan providers to be involved in the fisheries economy and marine industry. The involvement of the private sector in the fishing pawn business plays a role in expanding the economic base, equalizing income distribution and increasing financial inclusion in the marine economic sector. In addition, increasing the capacity and diversity of financial service providers needs to be strengthened by providing loans to environmentally friendly fisheries business actors. This is because the marine sector plays an important role in efforts to reduce carbon emissions and global warming which has an effect on climate change throughout the world. The ocean is one of the main carbon dioxide sinks, and the damage to the ocean caused by the unsustainable fishing industry has worsened the carbon sequestration capacity of the atmosphere. Because the fishing industry is closely related to the financial services sector as a lender, the government is encouraged to provide stricter regulations on the financial sector, both banking and non-banking, such as private pawnshops, to provide loans to environmentally friendly fisheries.

\section{Conclusion}

This study aims to find facts and analyze the existence of private pawning in the development of the fishing industry and its environmentally friendly approach. In Indonesia, the existence of private pawnshops has experienced rapid development, both in terms of regulation and supervision. In the past, private pawning did not have regulation and supervision, so it often caused losses to the parties due to various deviations from the principles of pawning. Since the issuance of the Financial Services Authority Regulation Number 31/POJK.05/2016 concerning the private pawnshop business, it has become a legal business entity. This is to make it easier to supervise, so that the existence of private pawning becomes a legal business. Therefore, the development of private pawnshops in various fields, including the development of the fishing industry, is very potential, but it turns out that not many private pawns have been registered and obtained permits.

The existence of private pawnshops is now a non-bank financing business which has been legalized since the existence of the Financial Services Authority Regulation. This private pawn has progressed when viewed from the number of registered private pawns and the value of financing provided to customers. However, the existence of legal private pawns is still not widely known to the public, including its use in the development of the fishing industry.

This finding underscores the enormous potential for developing the fishing industry which can potentially increase the existence of private pawnshops. Small number of private pawnshop companies and the rapid increase of marine business investment can be an opportunity for pawnshops to finance environmentally friendly fishing industries to more actively contribute in reducing global warming and carbon emissions. In particular, this study emphasizes the need for efforts to provide adequate financial guarantees to small and medium-sized businesses in the fisheries sector, and at the same time involve small and medium-scale fisheries businesses to protect the marine environment while increasing income from sustainable economy.

As recommendation, the government should conduct massive socialization of private pawning to the public by collaborating with various parties, namely academics, business actors and community leaders, to provide more legal protection for business actors and customers.

\section{Acknowledgement}

Authors would like to thank the Chancellor of Diponegoro University, Dean of the Faculty of Law of Diponegoro University, Institute for Research and Community Service (LPPM), Diponegoro University, Financial Services Authority Regulation (OJK), and National Legal Development Agency for research and financial supports. 


\section{REFERENCES}

[1] Geospatial Information Agency and Center for Hydrography and Oceanography of the Indonesian Navy, "Data Kelautan yang Menjadi Rujukan Nasional Diluncurkan," Available: https://www.pushidrosal.id/berita /5256/data-kelautan-yang-menjadi-rujukan-nasional--dilun curkan/, 2018 (Accessed Nov 3, 2021).

[2] Ministry of Marine Affairs, "Kementerian Kelautan dan Perikanan Tahun 2020-2024," Jakarta: Ministry of Marine Affairs, 2020.

[3] Badriyah S., Mahmudah S., Soemarmi A., "Aspek hukum leasing dan Usaha Perikanan Tangkap," Semarang: CV Tigamedia Pratama, 2019.

[4] Khairijah, "Aspek Hukum Pemanfaatan Zona Ekonomi Eksklusif Dalam Rangka Peningkatan Pendapatan Nelayan Indonesia," Available: http://bphn.go.id/data/documents/as pek_hukum_pemanfaatan_zona_ekonomi_eksklusif dalam rangka_peningkatan_pendapatan_nelayan_indonesia.pdf, 2005 (Accessed Nov 3, 2021).

[5] Crosetto P., Regner T., "It's never too late: Funding dynamics and self pledges in reward-based crowdfunding," Research Policy, vol. 47, no. 8, pp. 1463-1477, 2018.

[6] Ismail A. G., Ahmad N. Z., "Pawnshop as an instrument of microenterprise credit in Malaysia," International Journal of Social Economics, vol. 24, no. 11, pp. 1343-1353, 1997.

[7] Nurhayati A., Aisah I., Supriatna A. K., "Model Development of a Synergistic Sustainable Marine Ecotourism: A Case Study in Pangandaran Region, West Java Province, Indonesia," Sustainability, vol. 11, no. 12, pp. 3418, 2019.

[8] Yonvitner, Lioret J., Boer M., Kurnia R., Akmal S. G., Yuliana E., Yani D. E., Gómez S., Setijorini L. E., "Vulnerability of marine resources to small - scale fishing in a tropical area: The example of Sunda Strait in Indonesia," Fisheries Management and Ecology, vol. 27, no. 5, pp. 472-480, 2020.

[9] Djoher A., "Desalination Projects in Algeria: What Are the Environmental and Economic Issues of Seawater Desalination?" Environment and Ecology Research, vol. 8, no. 3, pp. 59 - 69, 2020. DOI: 10.13189/eer.2020.080301

[10] Andriansyah, Sulastri E., Satispi E., "The role of government policies in environmental management," Research Horizon, vol. 1, no. 3, pp. 86-93, 2021.

[11] Abubakar L., Handayani T., "Telaah Yuridis Perkembangan Regulasi Dan Usaha Pergadaian Sebagai Pranata Jaminan Kebendaan," Jurnal Bina Mulia Hukum, vol. 2, no. 1, pp. 80-92, 2017.

[12] Arkhipkin A. I., Rodhouse P. G. K., Pierce G. J., Sauer W., Sakai M., Allcock L., Arguelles J. et al., "World squid fisheries," Reviews in Fisheries Science \& Aquaculture, vol. 23, no. 2, pp. 92-252, 2015.

[13] Sadma O., "The Role of Environmental-Based "Green Startup" in Reducing Waste Problem and its Implication to
Environmental Resilience," Research Horizon, vol. 1, no. 3, pp. 106-114, 2021.

[14] Pratama W. P., "Jumlah Perusahaan Gadai Meningkat Pesat di Masa Pandemi Covid, ini Penjelasan OJK," Available: Bisnis.com, https://finansial.bisnis.com/read/20210106/89/ 1339269/jumlah-perusahaan-gadai-meningkat-pesat-di-ma sa-pandemi-ini-penjelasan-ojk, 2021 (Accessed Nov 3, 2021).

[15] Sapari A., "Country Fisheries Trade: Indonesia," Southeast Asian Fisheries Development Center (SEAFDEC), 2019. Retrieved from http://www.seafdec.org/country-trade-indo nesia/

[16] Yousuf M., "Challenges and Opportunities of Artificial Insemination on Dairy Cattle in Ethiopia," Research Horizon, vol. 1, no. 2, pp. 47-54, 2021.

[17] López-Martínez G., Schriewer K., Meseguer-Sánchez V., "Small-Scale Fishing and Sustainability. An Ethnographic Approach to the Case of Self-Employed Fishermen in the South-East of Spain," Sustainability, vol. 13, no. 19, pp. 10542, 2021.

[18] Kosamu I. B. M., "Conditions for sustainability of small-scale fisheries in developing countries," Fisheries Research, vol. 161, pp. 365-373, 2015.

[19] Salas S., Barragán-Paladines M. J., Chuenpagdee R., eds., "Viability and sustainability of small-scale fisheries in Latin America and the Caribbean," Springer, vol. 19, 2018.

[20] Purba N. M. B., Rebala L. T. S., Trihastuti N., "The Role of the State in Providing Public Services for the Utilization of Marine Resources," Environment and Ecology Research, vol.9, no. 5, pp. $209-214,2021$.

[21] Permana I., Dewi R., Budhiana J., Mariam I., Novianty L., Utami R. N., Sanjaya W., La Ede A. R., "Socio-Cultural Approach on Disaster Risk Management of Sirnaresmi Customary Village, West Java," Research Horizon, vol. 1, no. 4, pp. 136-142, 2021.

[22] Kittinger J. N., Finkbeiner E. M., Ban N. C., Broad K., Carr M. H., Cinner J. E., Gelcich S. et al., "Emerging frontiers in social-ecological systems research for sustainability of small-scale fisheries," Current Opinion in Environmental Sustainability, vol. 5, no. 3-4, pp. 352-357, 2013.

[23] Ahmed N., Rahman S., Bunting S. W., Brugere C., "Socio - economic and ecological challenges of small scale fishing and strategies for its sustainable management: A case study of the Old Brahmaputra River, Bangladesh," Singapore Journal of Tropical Geography, vol. 34, no. 1, pp. 86-102, 2013

[24] Yuvaraj R. M., “Assessment of Land Use/Land Cover and Its Dynamic Using Geospatial Techniques in Pudukkottai District of Tamil Nadu, India," Environment and Ecology Research, vol. 8, no. 4, pp. 85 - 99, 2020. DOI: 10.13189/eer.2020.080401

[25] Schuhbauer A., Chuenpagdee R., Cheung W. W. L., Greer K., Sumailal U. R., "How subsidies affect the economic viability of small-scale fisheries," Marine Policy, vol. 82, pp. 114-121, 2017.

[26] Jacquet J., Pauly D., "Funding priorities: big barriers to small - scale fisheries," Conservation biology, vol. 22, no. 
4, pp. 832-835, 2008.

[27] Badriyah S. M., Suharto R. B., Kashadi, Mahmudah, Soemarmi A., "Private Pawnshop Registration as an Effort to Develop Small and Medium Enterprises in Indonesia," International Journal of Innovation, Creativity and Change, vol. 12, no. 7, pp. 174-185, 2020.

[28] Badriyah S. M., Suharto R., Marjo, "Reorientasi Usaha Pegadaian Swasta Sebagai Upaya Keseimbangan Hubungan Hukum Para Pihak Di Indonesia," Jurnal IUS Kajian Hukum dan Keadilan, vol. 7, no. 3, pp. 534-548, 2019.

[29] Borres I. L., "Industry Analysis of Pawnshop in the Philippine," International Journal of Business and Administrative Studies, vol. 6, no. 2, pp. 111-120, 2020.
[30] Andryushchenko G. I., Andryushchenko A. M., Maloletko A. N., Savina M. V., Solodukha P. V., "Risks of Developing the Pawnshops Market in the Russian Federation," International Journal of Applied Business and Economic Research, vol. 15, no. 8, pp. 117-125, 2017.

[31] Huian M., "Some considerations on accounting for pawnshops in Romania," München: University Library of Munich, 2009.

[32] Pomeroy R., Arango C., Lomboy C. G., Box S., "Financial inclusion to build economic resilience in small-scale fisheries," Marine policy, vol. 118, pp. 103982, 2020.

[33] Pranata N., "Financial inclusion in Indonesia's fishery sector: Factors determining credit participation," Institutions and Economies, pp. 51-77, 2019. 